Trace element pollution of soils by abandoned gold mine tailings near Potchefstroom, South Africa

by

\title{
PAUL-JOHAN AUCAMP
}

Submitted in partial fulfilment of the requirements

for the degree of

\section{MAGISTER SCIENTIAE}

in the Faculty of Science of the

University of Pretoria

\section{PRETORIA}

2000 


\title{
Trace element pollution of soils by abandoned gold mine tailings near Potchefstroom, South Africa
}

by

\section{PAUL-JOHAN AUCAMP}

Supervisor:

Co-Supervisor:

Degree:
Prof A van Schalkwyk

Prof MC Laker

Magister Scientiae in Engineering and Environmental Geology

\begin{abstract}
The extent to which trace elements from reworked tailings have polluted the underlying soils at the abandoned Machavie Gold Mine was investigated. Material from five tailings dams has been reworked by wind and water erosion and deposited over an area of $\pm 1,1 \mathrm{~km}^{2}$ downslope from the tailings impoundments. The tailings deposit varies in thickness between $0,01 \mathrm{~m}$ to $1,50 \mathrm{~m}$. The influence of this tailings cover on the underlying soils was investigated by means of a series of test pits from which disturbed samples were retrieved. The investigated soils consist of residual dolomitic soils overlain by colluvial and alluvial soils. The tailings is a source of contamination as it produces trace element-rich acidic leachate from the decomposition of sulphide minerals in the tailings. The average $\mathrm{pH}$ of the tailings is very acidic at 3,43 . Soluble sulphate salts that have precipitated on the reworked tailings, show high water-soluble concentrations of $\mathrm{As}, \mathrm{Cd}, \mathrm{Co}, \mathrm{Cr}, \mathrm{Cu}, \mathrm{Ni}, \mathrm{Pb}$ and $\mathrm{Zn}$. All the soils directly underlying the reworked tailings are affected by the acidic, trace element rich-leachate produced in the tailings. The trace element content of the tailings and soils was compared with the guideline concentrations which indicate that the soils and tailings should be further investigated for As, $\mathrm{Co}$, $\mathrm{Cr}, \mathrm{Cu}$ and $\mathrm{Ni}$ contamination. To assess the degree of contamination in the soils, extractable concentrations of $\mathrm{As}, \mathrm{Co}, \mathrm{Cr}, \mathrm{Cu}, \mathrm{Ni}, \mathrm{Pb}$ and $\mathrm{Zn}$ were determined by using $\mathrm{NH}_{4} \mathrm{NO}_{3}$, which is recommended by various authors as an environmental leaching agent. An ammonium nitrate extractable Zn-equivalent was introduced and used to show that the upper clayey alluvial soils pose a greater threat to plant life than the sandy colluvial soils. The mobility of the trace elements was investigated by determining the percentage of the total element concentration which is extractable with $\mathrm{NH}_{4} \mathrm{NO}_{3}$. Trace element mobilities increase with lower soil $\mathrm{pH}$ values once a $\mathrm{pH}$ of 5 is reached.
\end{abstract}


Trace element pollution of soils by abandoned gold mine tailings

near Potchefstroom, South Africa

by

\title{
PAUL-JOHAN AUCAMP
}

\author{
Supervisor: $\quad$ Prof A van Schalkwyk \\ Co-Supervisor: $\quad$ Prof MC Laker \\ Degree: $\quad$ Magister Scientiae in Engineering and Environmental Geology
}

\section{SAMEVATTING}

Die ondersoek handel oor die mate waartoe grond wat oorlê word deur goudmynslik, deur sekere spoorelemente besoedel word. Die studie area is die geslote Machavie goudmyn wat oos van Potchefstroom, in die Noordwes Provinsie gelee is. In die studie area is ' $\mathrm{n}$ gebied van $\pm 1,1 \mathrm{~km}^{2}$ besoedel deur wind en water verspreide goudmynslik afkomstig van vyf slikdamme. Die dikte van die slik wissel tussen $0,01 \mathrm{~m}$ en $1,50 \mathrm{~m}$. Die invloed van die goudmynslik op die onderliggende gronde is ondersoek deur die grawe van ' $n$ aantal toetsgate waaruit versteurde grondmonsters verkry is. Die gronde in die studie area bestaan uit residuele dolomiet wat oorlê word deur kolluviale en alluviale gronde. Die goudmynslik kan as ' $n$ bron van suur en spoorelementbesoedeling beskou word aangesien die slik ' $\mathrm{n}$ gemiddelde $\mathrm{pH}$ (water) van 3,43 het, en oplosbare soute wat neergeslaan het op die oppervlakte van die herwerkte slik, hoë water oplosbare konsentrasies van $\mathrm{As}, \mathrm{Cd}, \mathrm{Co}, \mathrm{Cr}, \mathrm{Cu}, \mathrm{Ni}, \mathrm{Pb}$ en $\mathrm{Zn}$, bevat. Die meerderheid grond wat oorlê word deur die slik, is geaffekteer deur die slik aangesien die gronde lae pH's het. Die spoorelement inhoud van die gronde is vergelyk met internasionale limiet konsentrasies, en daar is bevind dat die konsentrasies van $\mathrm{As}, \mathrm{Co}, \mathrm{Cr}, \mathrm{Cu}$ en $\mathrm{Ni}$ in die gronde verder ondersoek moet word. Ammoniumnitraat is gebruik as 'n loginsmiddel om die ekstraheerbare konsentrasies van As, $\mathrm{Co}, \mathrm{Cr}, \mathrm{Cu}, \mathrm{Ni}, \mathrm{Pb}$ en $\mathrm{Zn}$ in die gronde te bepaal. ' $\mathrm{n} \mathrm{NH}_{4} \mathrm{NO}_{3}$ ekstraheerbare $\mathrm{Zn}$-ekwivalent is gebruik om te wys dat die kleierigge alluviale bogrond ' $n$ groter gevaar vir plantlewe inhou as die sanderigge kolluviale bogrond. Die mobiliteit van die spoorelemente is ondersoek deur die persentasie van die totale spoorelement inhoud wat ekstraheerbaar deur $\mathrm{NH}_{4} \mathrm{NO}_{3}$ is, te bepaal. Daar is bewys dat spoorlement mobilitiet ' $\mathrm{n}$ funksie van die $\mathrm{pH}$ van die grond is, aangesien hoër spoorelement mobiliteite onder ' $\mathrm{n} \mathrm{pH}$ van 5 voorkom. 


\section{ACKNOWLEDGEMENTS}

I would like to extend my sincere appreciation to the following persons and institutions:

- The Council for Geoscience for their financial, technical and scientific assistance.

- $\quad$ Professors van Schalkwyk and Laker for their guidance and support.

- Mr Willie van Zyl of the Department of Minerals and Energy Affairs for suggesting a suitable research site.

and finally, to my wife Elzanne for her support. 


\section{TABLE OF CONTENTS}

PAGE

\section{CHAPTER 1 INTRODUCTION}

1.1 INTRODUCTION $\ldots \ldots \ldots \ldots \ldots \ldots \ldots \ldots \ldots \ldots \ldots \ldots \ldots \ldots \ldots$

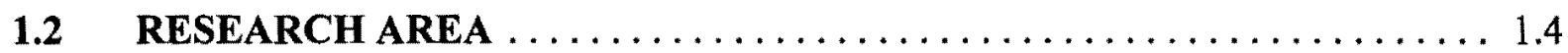

1.3 OBJECTIVES OF RESEARCH AND LAYOUT OF DISSERTATION $\ldots 1.4$

1.3.1 Objectives of the research $\ldots \ldots \ldots \ldots \ldots \ldots \ldots \ldots \ldots \ldots \ldots \ldots \ldots \ldots \ldots$

1.3.2 Layout of dissertation $\ldots \ldots \ldots \ldots \ldots \ldots \ldots \ldots \ldots \ldots \ldots \ldots \ldots \ldots$

\section{CHAPTER 2 LITERATURE SURVEY}

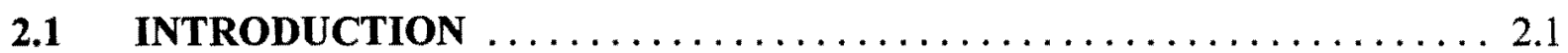

2.2 NATURAL CONCENTRATIONS OF TRACE ELEMENTS IN SOILS . . . 2.1

2.2.1 Geochemical origin of trace elements in soils $\ldots \ldots \ldots \ldots \ldots \ldots \ldots .1$

2.2.2 Pedogenic processes that translocate trace elements in soils . . . . . . 2.3

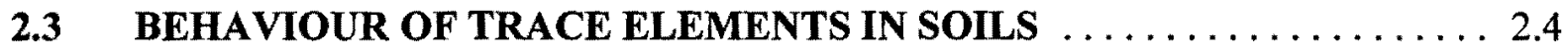

2.4 THE INFLUENCE OF pH AND REDOX CONDITIONS ON THE MOBILITY OF TRACE ELEMENTS $\ldots \ldots \ldots \ldots \ldots \ldots \ldots \ldots \ldots \ldots$

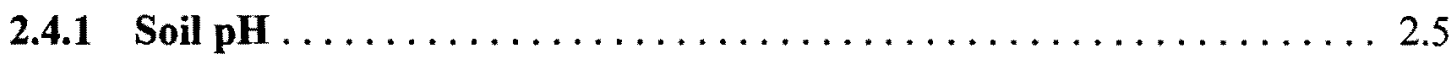

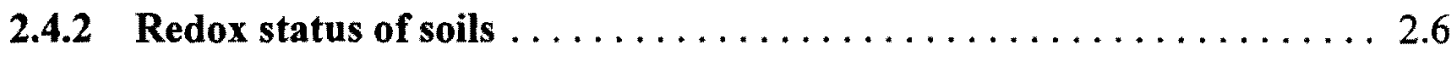

2.5 NATURAL AND PROVOKED MOBILIZATION OF TRACE

ELEMENTS IN SOILS AND SEDIMENTS $\ldots \ldots \ldots \ldots \ldots \ldots \ldots \ldots$

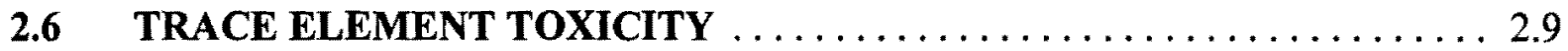

2.7 GEOCHEMICAL BEHAVIOR OF CERTAIN TRACE ELEMENTS . . . 2.11

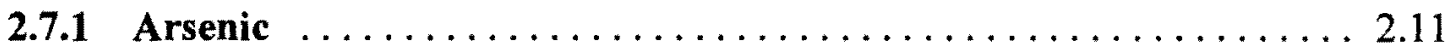

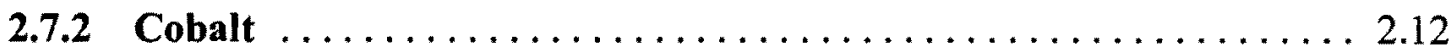

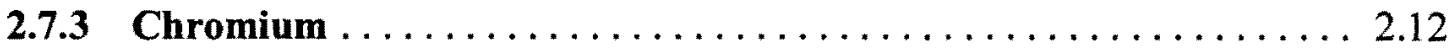

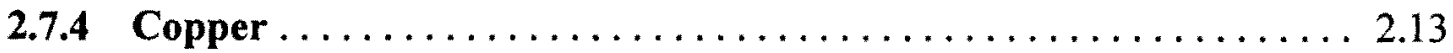




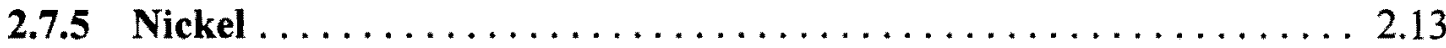

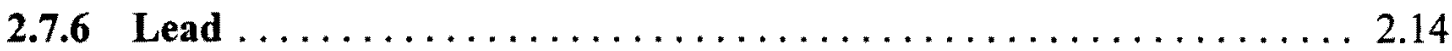

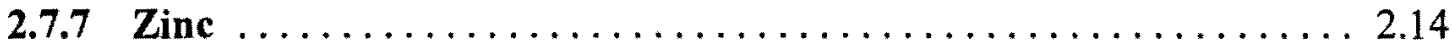

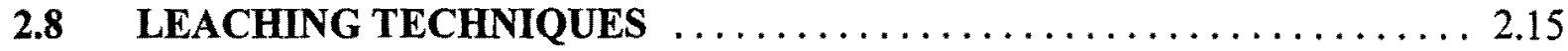

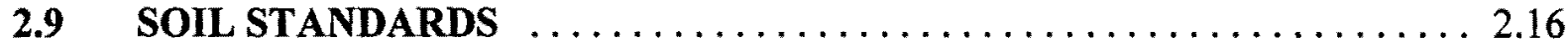

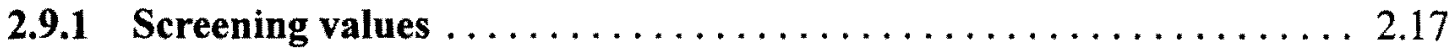

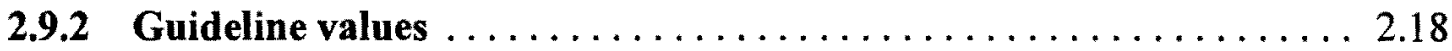

2.10 RISK ASSESSMENT OF METAL POLLUTION IN SOILS . . . . . . . 2.19

2.10.1 Exposure assessment $\ldots \ldots \ldots \ldots \ldots \ldots \ldots \ldots \ldots \ldots \ldots \ldots \ldots \ldots \ldots \ldots \ldots .19$

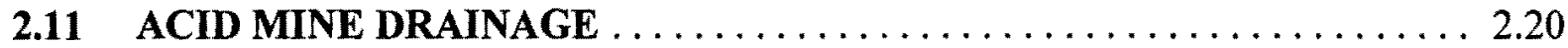

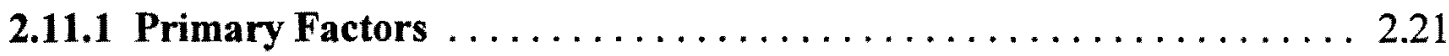

2.11.2 Limiting factors $\ldots \ldots \ldots \ldots \ldots \ldots \ldots \ldots \ldots \ldots \ldots \ldots \ldots \ldots \ldots \ldots \ldots \ldots .22$

2.11.3 Secondary factors $\ldots \ldots \ldots \ldots \ldots \ldots \ldots \ldots \ldots \ldots \ldots \ldots \ldots \ldots \ldots \ldots \ldots$

2.11.4 Tertiary factors $\ldots \ldots \ldots \ldots \ldots \ldots \ldots \ldots \ldots \ldots \ldots \ldots \ldots \ldots \ldots \ldots \ldots \ldots .23$

2.11.5 Downstream factors $\ldots \ldots \ldots \ldots \ldots \ldots \ldots \ldots \ldots \ldots \ldots \ldots \ldots \ldots \ldots \ldots \ldots \ldots .24$

2.11.6 Trace elements associated with sulphide minerals . . . . . . . . 2.24

2.11.7 Environmental affects of gold mine tailings in South African . . . . . 2.25

\section{CHAPTER 3 DESCRIPTION OF THE STUDY AREA}

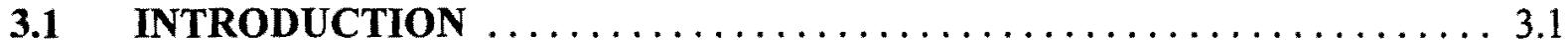

3.1.1 Locality and site history $\ldots \ldots \ldots \ldots \ldots \ldots \ldots \ldots \ldots \ldots \ldots \ldots \ldots \ldots \ldots \ldots$

3.1.2 Available information $\ldots \ldots \ldots \ldots \ldots \ldots \ldots \ldots \ldots \ldots \ldots \ldots \ldots \ldots \ldots \ldots \ldots$

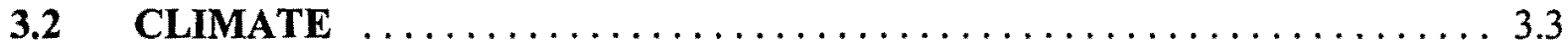

3.2.1 Regional climate of the Potchefstroom - Klerksdorp area . . . . . . . 3.3

3.2.2 Mean monthly and annual rainfall of the Potchefstroom area . . . . . 3.3

3.2.3 Mean monthly maximum and minimum temperatures $\ldots \ldots \ldots \ldots .3$

3.2.4 Mean monthly wind direction and speed $\ldots \ldots \ldots \ldots \ldots \ldots .4$

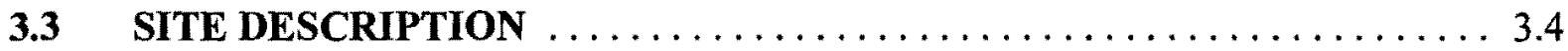

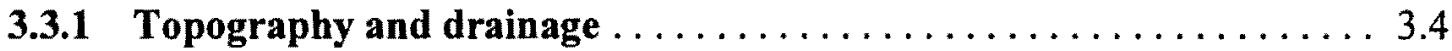




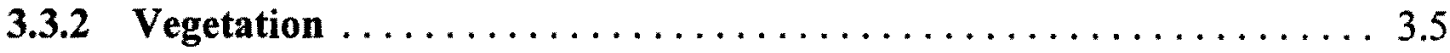

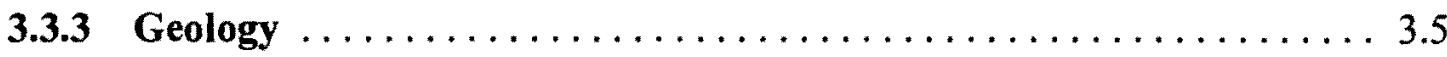

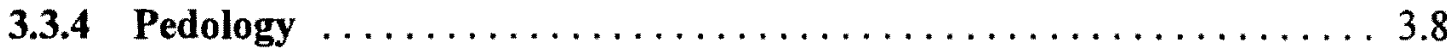

\section{CHAPTER 4 DESCRIPTION OF SOILS}

4.1 INTRODUCTION $\ldots \ldots \ldots \ldots \ldots \ldots \ldots \ldots \ldots \ldots \ldots \ldots \ldots \ldots \ldots \ldots$

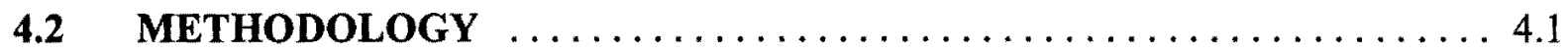

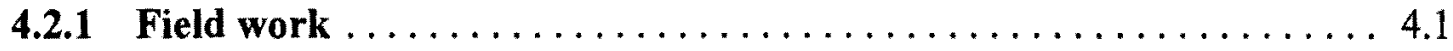

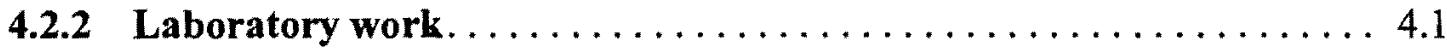

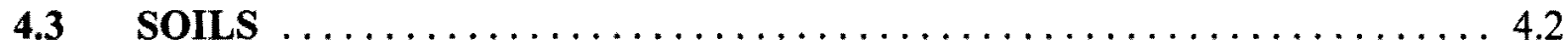

4.3.1 Colluvial soil descriptions and geotechnical properties. . . . . . 4.2

4.3.2 Alluvial soil descriptions and geotechnical properties .... . . . 4.4

4.4 TAXONOMIC CLASSIFICATION AND GENERAL DESCRIPTION

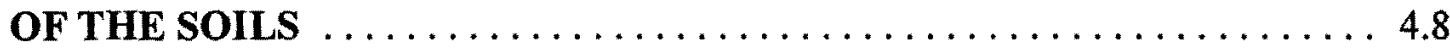

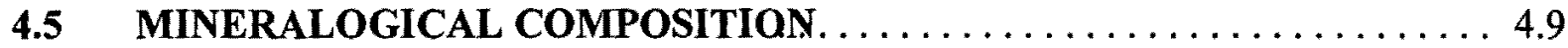

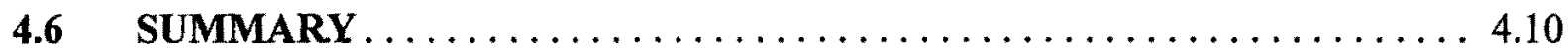

\section{CHAPTER 5 GOLD MINE TAILINGS AS A SOURCE OF CONTAMINATION}

5.1 INTRODUCTION. . . . . . . . . . .

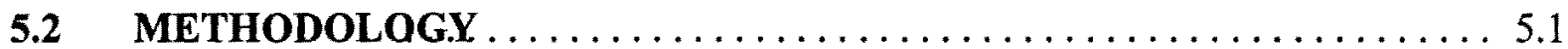

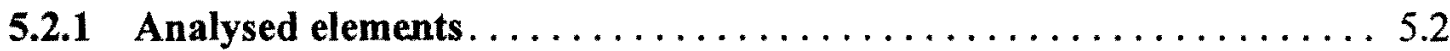

5.3 TAILINGS AS A SOURCE OF TRACE ELEMENT CONTAMINATION . . 5.2 5.3.1 Salts precipitated on the tailings dams $\ldots \ldots \ldots \ldots \ldots \ldots \ldots \ldots .4$

5.4 THE INFLUENCE OF THE TAILINGS ON THE pH AND EC OF THE UNDERLYING SOILS $\ldots \ldots \ldots \ldots \ldots \ldots \ldots \ldots \ldots$

5.4 .1 Tailings. . . . . . . . . . .

5.4 .2 Colluvial soils $\ldots \ldots \ldots \ldots \ldots \ldots \ldots \ldots \ldots \ldots \ldots \ldots \ldots \ldots \ldots \ldots \ldots \ldots$

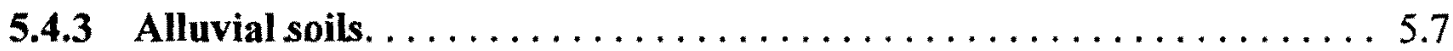


5.5 TRACE ELEMENT SOIL CONTAMINATION

5.5.1 Trace element concentrations in the affected soils compared with guideline values $\ldots \ldots \ldots \ldots \ldots \ldots \ldots \ldots \ldots \ldots \ldots \ldots$

5.5.1.1 Tier one analyses (Dutch $\mathrm{A}$ - value screening) $\ldots \ldots \ldots \ldots .10$

5.5.1.2 Tier two screening (Dutch B concentrations). . . . . . . . . 5.11

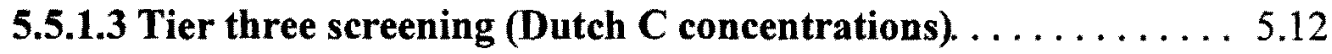

5.6 VERTICAL AND LATERAL TRACE ELEMENT CONCENTRATIONS. 5.13

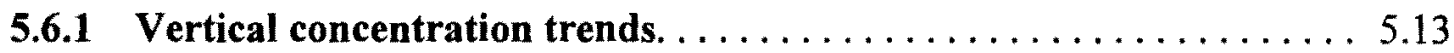

5.6.1.1 Discussion of vertical trace element concentration trends . . . 5.15

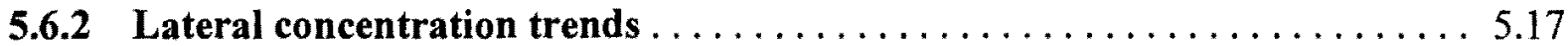

5.6.2.1 Discussion of lateral trace element concentration trends . . . 5 5.20

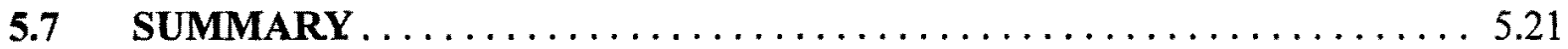

\section{CHAPTER 6 TRACE ELEMENT MOBILITIES}

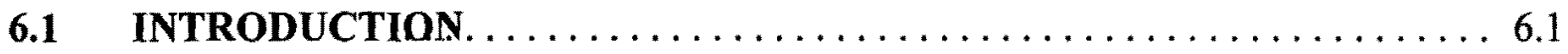

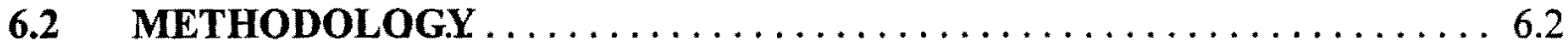

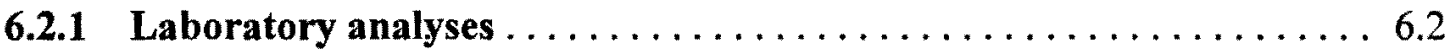

6.2.2 Selection of the $\mathrm{NH}_{4} \mathrm{NO}_{3}$ extraction method $\ldots \ldots \ldots \ldots \ldots \ldots \ldots .2$

6.2.3 Detection limits, reliability of results and adjustment of results . . . . 6.3

6.2.4 $1 \mathrm{M} \mathrm{NH} \mathrm{NO}_{3}$ extractable guideline concentrations and

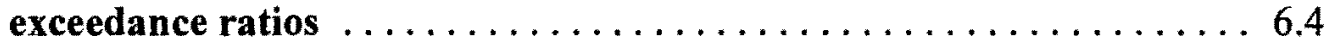

6.2.5 Calculation of zinc-equivalents $\ldots \ldots \ldots \ldots \ldots \ldots \ldots \ldots \ldots \ldots \ldots \ldots \ldots \ldots \ldots$

6.2.6 Calcualtion of trace element mobilities $\ldots \ldots \ldots \ldots \ldots \ldots \ldots \ldots$

6.3 RESULTS AND DISCUSSION OF EXTRACTABLE TRACE

ELEMENT CONCENTRATIONS $\ldots \ldots \ldots \ldots \ldots \ldots \ldots \ldots \ldots \ldots$

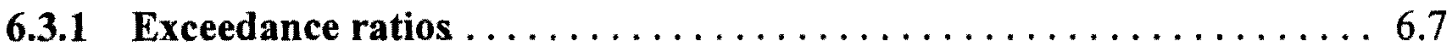

6.3.2 Zinc equivalents (implication of contamination for plants) $\ldots \ldots \ldots 6.8$

6.3.3 Vertical and lateral extractable trace element concentration trends . . . . . . . . . . . . . . . . . . . . . . . 6.10

6.3.3.1 Vertical extractable trace element concentration trends . . . 6.10 
6.3.3.2 Lateral extractable trace element concentration trends

6.4 RESULTS AND DISCUSSION OF TRACE ELEMENT MOBILITY

6.4.1 Vertical trace element mobility trends

6.4.2 Lateral trace element mobility trends.

6.5 RESULTS AND DISCUSSION OF TRACE ELEMENT MOBILITY

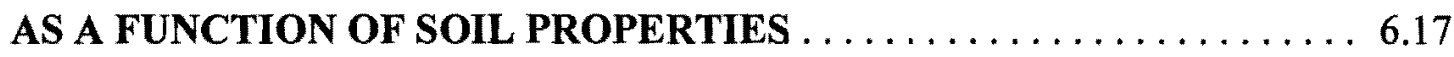

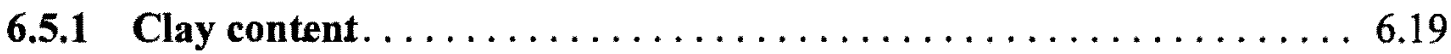

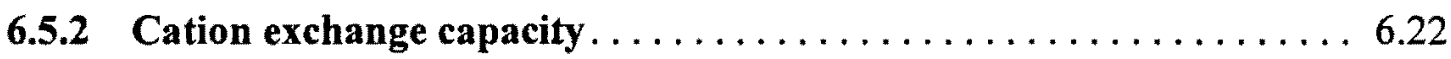

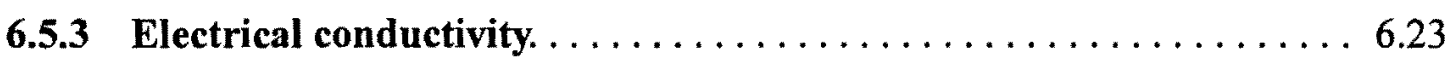

6.5.4 Trace element mobility as a function of $\mathrm{pH} \ldots \ldots \ldots \ldots \ldots .23$

6.5.4.1 Tailings $\ldots \ldots \ldots \ldots \ldots \ldots \ldots \ldots \ldots \ldots \ldots \ldots \ldots \ldots \ldots \ldots \ldots .27$

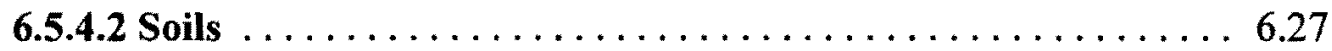

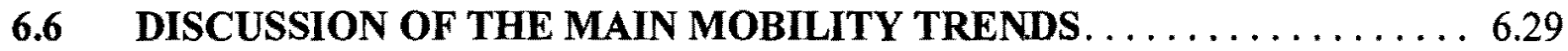

6.6.1 Explanations of main mobility trends $\ldots \ldots \ldots \ldots \ldots \ldots \ldots .6 \ldots$

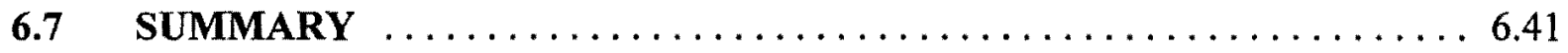

\section{CHAPTER 7 CONCLUSIONS AND RECOMMENDATIONS}

7.1 CONCLUSIONS $\ldots \ldots \ldots \ldots \ldots \ldots \ldots \ldots \ldots \ldots \ldots \ldots \ldots \ldots \ldots \ldots \ldots$

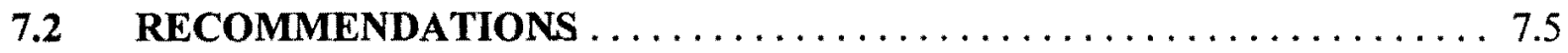

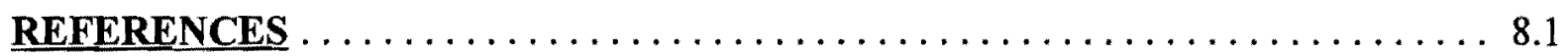

APPENDIX A $\quad$ Geotechnical properties $\ldots \ldots \ldots \ldots \ldots \ldots \ldots \ldots \ldots \ldots \ldots \ldots \ldots \ldots$

APPENDIX B $\quad$ Mineralogy of the tailings and soils $\ldots \ldots \ldots \ldots \ldots \ldots \ldots .1$

APPENDIX $\mathrm{C} \quad$ Total element XRF analyses $\ldots \ldots \ldots \ldots \ldots \ldots \ldots \ldots \ldots \ldots \ldots \ldots \ldots$

APPENDIX D $\quad \mathrm{NH}_{4} \mathrm{NO}_{3}$ extractable trace element concentrations, exceedance ratios and trace element mobilities .............. D. 1

APPENDIX E Cation exchange capacities of some soil and tailings samples .. E.1 


\section{LIST OF TABLES}

Table 2.1 Descriptive terms and proposed buffering mechanisms for the soil $\mathrm{pH}$

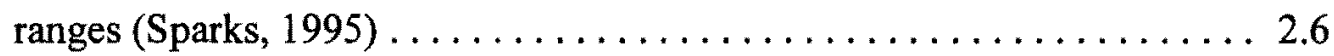

Table 2.2. Relative mobilities of elements in sediments and soils as function of Eh and $\mathrm{pH}$ after Förstner \& Kersten (1988), cf, references therein) $\ldots \ldots \ldots 2.9$

Table 2.3 Biological function and toxicity of some trace elements (after McBride 1994) .............................. 2.10

Table 2.4 Maximum permissible total soil concentrations of trace elements used in legislation or in guidelines for various countries as summarized by Steyn et al. (1996). All values are in $\mathrm{mg} / \mathrm{kg}$ dry soil for the $<2 \mathrm{~mm}$ soil fraction $\ldots 2.17$

Table 2.5 Recommended maximum $\mathrm{NH}_{4} \mathrm{NO}_{3}$ extractable threshold concentration $(\mathrm{mg} / \mathrm{l})$ that should not be exceeded in the soil (from Schoelmann (1996) after Prüeß, Turian $\&$ Schweikle (1991)) . . . . . . . . . . . . 2.18

Table 2.6 Common ore minerals of non-ferrous metals and their associated trace

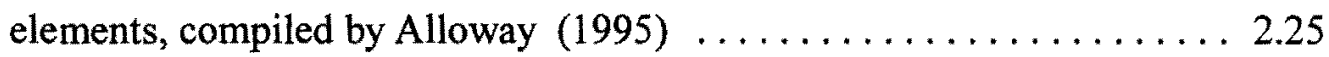

Table 3.1 The averaged monthly rainfall and maximum 24 hour rainfall for the Potchefstroom area as well as average monthly A-pan equivalent evaporation data (Weather Bureau, 1995) . . . . . . . . . 3.3

Table 3.2 Mean monthly maximum and minimum temperatures $\left({ }^{\circ} \mathrm{C}\right)$ from the Potchefstroom area (Weather Bureau, 1995) . . . . . . . . . 3.4

Table 3.3 The stratigraphy of the investigated area $\ldots \ldots \ldots \ldots \ldots \ldots \ldots$

Table 4.1 Schedule of the routine soils testing and test methods $\ldots \ldots \ldots \ldots .2$

Table 4.2 Colluvial soil unit description and percentage of Unified Soil Classification

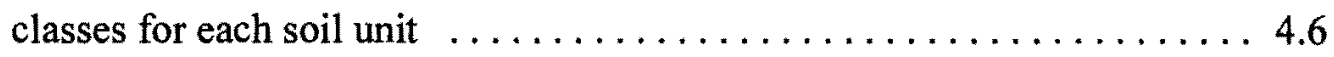

Table 4.3 Alluvial soil unit description and percentage of Unified Soil Classification classes for each soil unit $\ldots \ldots \ldots \ldots \ldots \ldots \ldots \ldots \ldots \ldots .7$

Table 4.4 Average mineralogical compositionsof the some tailings, colluvial and alluvial soil samples $\ldots \ldots \ldots \ldots \ldots \ldots \ldots \ldots \ldots \ldots \ldots$ 
Table 5.1 Detection limits for the Philips PW 1606 Simultaneous X-ray Fluorescence

Spectrometer (after Elsenbroek, 1996). All values in $\mathrm{mg} / \mathrm{kg}$

Table 5.2. The average maximum trace element content (AMTEC) of pyrite of the Black Reef Formation in $\mathrm{mg} / \mathrm{kg}$ (after Barton \& Hallbauer, 1996) . . . 5.3

Table 5.3 Trace element composition (in $\mathrm{mg} / \mathrm{kg}$ except $\mathrm{Fe}_{2} \mathrm{O}_{3} \mathrm{t}$ and $\mathrm{MnO}$ ) of pyrite of the Black Reef Formation from the discard ore dump at Machavie gold mine

Table 5.4 Water soluble concentrations of $\mathrm{As}, \mathrm{Cd}, \mathrm{Co}, \mathrm{Cr}, \mathrm{Cu}, \mathrm{Ni}, \mathrm{Pb}$ and $\mathrm{Zn}(\mathrm{mg} / \mathrm{l})$ in the white and yellow precipitate occurring on the

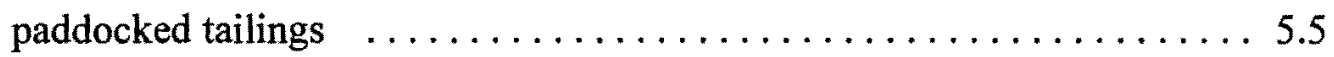

Table 5.5 Dutch ABC guideline concentrations and South African soil

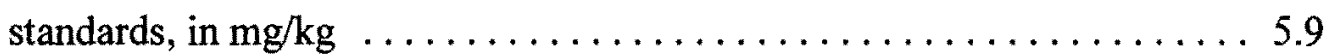

Table 5.6 Frequency (percentage of samples) and range of ratio's by which concentrations of selected elements exceed the Dutch A values (DATC) in the soils and tailings

Table 5.7 Frequency (percentage of samples) and range of ratio's by which concentrations of selected elements exceed the Dutch B (DBTC) values In the soils and tailings

Table 6.1 Detection limits of $\mathrm{As}, \mathrm{Co}, \mathrm{Cr}, \mathrm{Cu}, \mathrm{Ni}, \mathrm{Pb}$ and $\mathrm{Zn}$ in a solution of $1 \mathrm{M} \mathrm{NH}_{4} \mathrm{NO}_{3}$ on the Liberty 200 ICP-AES in $\mathrm{mg} / \mathrm{l}$.

The wavelength at which each element was analysed as well as the power used during ionization is given. Element concentrations in the blank samples are reported in $\mathrm{mg} / \mathrm{l}$

Table 6.2 Guideline $1 \mathrm{MNH}_{4} \mathrm{NO}_{3}$ extractable threshold values for soils (mg/l) after

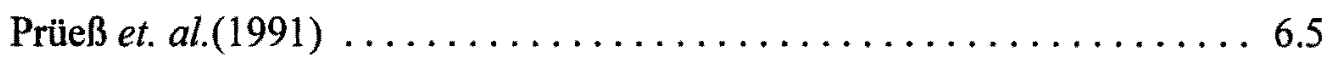

Table 6.3 Frequency (percentage of samples) and range of ratio's by which concentrations of selected elements from tailings and soils underlying the site exceed guidelines (refer to Table 6.2 ) $\ldots \ldots \ldots \ldots \ldots .6$ 
Table 7.1 Comparison between the results of the Dutch-B concentrations screening and the $\mathrm{NH}_{4} \mathrm{NO}_{3}$ extractable concentrations screening for the soils of the investigated area $\ldots \ldots \ldots \ldots \ldots \ldots \ldots \ldots .2$

Table A.1 Summary of geotechnical properties $\ldots \ldots \ldots \ldots \ldots \ldots \ldots$ A.2 - A.4

Table B.1 Mineralogical composition of some colluvial and alluvial soils (all results reported as percentages) $\ldots \ldots \ldots \ldots \ldots \ldots \ldots \ldots$ B.2

Table C.1 XRF analyses of tailings and the alluvial soils (all results reported in $\mathrm{mg} / \mathrm{kg}$ unless indicated $\ldots \ldots \ldots \ldots \ldots \ldots \ldots \ldots \ldots \ldots \ldots \ldots .2$

Table C.2 XRF analyses of tailings and the colluvial soils (all results reported in $\mathrm{mg} / \mathrm{kg}$ unless indicated) $\ldots \ldots \ldots \ldots \ldots \ldots \ldots \ldots \ldots \ldots \ldots \ldots$

Table D.1 $\mathrm{NH}_{4} \mathrm{NO}_{3}$ extractable trace element concentrations of the tailings and soils of the investigated transect (results reported in $\mathrm{mg} / \mathrm{l}$ ) . . . . . D.2

Table D.2 Trace element exceedance ratios in the tailings and soils of the investigated transect $\ldots \ldots \ldots \ldots \ldots \ldots \ldots \ldots \ldots \ldots \ldots$ D. 3

Table D.3 Trace element mobility (\%) in the tailings and soils of the investigated transect $\ldots \ldots \ldots \ldots \ldots \ldots \ldots \ldots \ldots \ldots \ldots \ldots \ldots$

Table E.1 Cation exchange capacities of some of the soil and tailings samples in the investigated transect $\ldots \ldots \ldots \ldots \ldots \ldots \ldots \ldots$ E.2 


\section{LIST OF FIGURES}

Figure 1.1 Recent historical changes in anthropogenic emissions of

$\mathrm{Cu}, \mathrm{Pb}$ and $\mathrm{Zn}$ to the atmosphere, after Nriagu (1996)

Figure 2.1 Dynamic equilibria reactions in soils after Lindsay (1979)

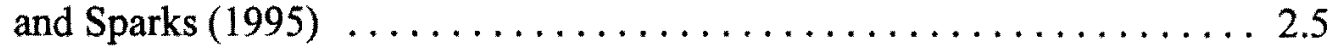

Figure 2.2 Speciation of trace elements in soils as a percentage of total content after Kabata-Pendias (1992)

Figure. 2.3 Some human exposure pathways to be considered when performing a risk assessment investigation of a heavy metal contaminated site (after Pierzynski et al.(1994)

Figure 3.1 Locality of the investigated transect indicating test pit positions relative to the tailings dams and the Kromdraai Spruit $\ldots \ldots \ldots \ldots \ldots \ldots . \ldots \ldots .2$

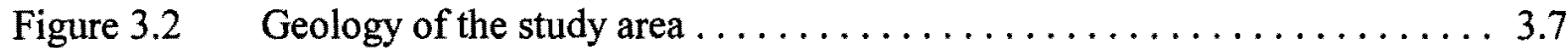

Figure 4.1 Cross section of the colluvial soils $\ldots \ldots \ldots \ldots \ldots \ldots \ldots \ldots \ldots$

Figure $4.2 \quad$ Cross section of the alluvial soils $\ldots \ldots \ldots \ldots \ldots \ldots \ldots \ldots \ldots \ldots$

Figure.5.1 Relationship between soil and tailings depth and $\mathrm{pH}$ in the colluvial soils. . . . . . . . . . . . . . . . . . . . . . . . . . . 5.8

Figure.5.2 Relationship between soil and tailings depth and $\mathrm{pH}$ in the

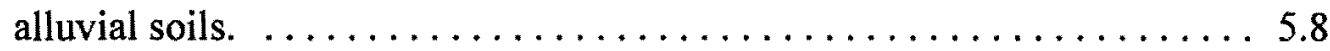

Figure 5.3 Vertical trace element concentrations in the soils and tailings of the investigated transect.

Figure 5.4 Lateral trends in trace element concentrations in some soils of the investigated transect

Figure 6.1 Lateral changes in the $\mathrm{NH}_{4} \mathrm{NO}_{3}$ extractable zinc-equivalent in the topsoil (units $\mathrm{AU}$ and $\mathrm{CU}$ ) along the investigated transect . .

Figure 6.2 Vertical $\mathrm{NH}_{4} \mathrm{NO}_{3}$ extractable zinc-equivalent concentrations in the colluvial and alluvial soils (soil units $\mathrm{CU}, \mathrm{CF}, \mathrm{AU}$ and $\mathrm{AL}$ )

Figure 6.3 Vertical trends in extractable trace element concentrations 6.12 
Figure $6.4 \quad$ Lateral extractable trace element concentration trends $\ldots \ldots \ldots \ldots .6 .14$

Figure 6.5 Vertical trends in trace element mobilities $\ldots \ldots \ldots \ldots \ldots \ldots \ldots .16$

Figure $6.6 \quad$ Lateral trends in trace element mobilities $\ldots \ldots \ldots \ldots \ldots \ldots \ldots .18$

Figure 6.7 Relationship between the clay content of the tailings and the trace element mobilities (note that the scale differs) $\ldots \ldots \ldots \ldots \ldots \ldots .20$

Figure 6.8 Relationship between the clay content of the soil and the trace element mobilities (note that the scale differs) $\ldots \ldots \ldots \ldots . \ldots \ldots 6.21$

Figure 6.9 Relationship between the cation exchange capacity of the soil and the trace element mobilities (note that the scale differs) . . . . . . 6.24

Figure 6.10 Relationship between the electrical conductivity of the tailings and the trace element mobilities (note that the scale differs) $\ldots \ldots \ldots 6.25$

Figure 6.11 Relationship between the electrical conductivity of the soil and the trace element mobilities (note that the scale differs) $\ldots \ldots \ldots 6.26$

Figure 6.12 Relationship between the $\mathrm{pH}$ of the tailings and the trace element mobilities (note that the scale differs) $\ldots \ldots \ldots \ldots \ldots .28$

Figure 6.13 Relationship between the $\mathrm{pH}$ of the soil and the trace element mobilities (note that the scale differs) $\ldots \ldots \ldots \ldots . \ldots 6.30$

Figure 6.14 Relationship between the clay content of the soil and the CEC

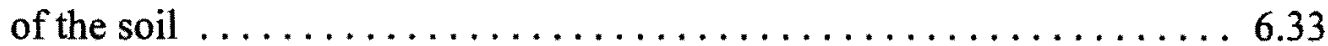

Figure 6.15 Relationship between the clay content and soil depth in the alluvial soils (sample MT5/5 not considered) . . . . . . . . . . 6.34

Figure 6.16 Lateral variation in the grainsize distribution of the tailings (Units TC and TA) between test pits MT28 to MT1 . . . . . . . . 6.37

Figure 6.17 Lateral changes in the $\mathrm{pH}$ of the tailings and upper soil units between test pits MT28 to MT1

Figure 6.18 Total trace element concentrations in the tailings (units TC and TA) as a function of the clay and silt fractions of each sample

Figure 6.19 Total trace element concentrations in the tailings (units TC and TA) as a function of the gravel and sand fractions of each sample 6.40 


\section{LIST OF PLATES}

Page

Plate5.1 The extent of soluble salts deposited on the paddocked tailings

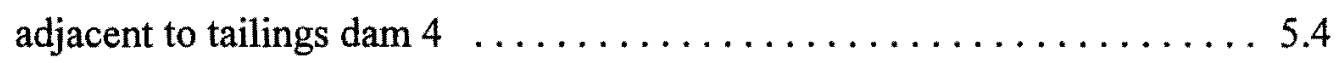

Plate5.2 Close-up of the yellowish and white soluble salts deposited on the paddocked tailings adjacent to tailings dam $4 \ldots \ldots \ldots \ldots .5$

Plate 5.3 Metal drums in tailings dam 4, corroded due to the acid nature

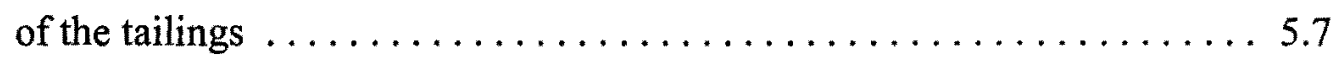

